\title{
Thermo-chemical equilibrium modeling and simulation of biomass gasification
}

\author{
Alexey Demin ${ }^{1, *}$, Roza Dyganova $^{1}$, and Nail Fakhreev ${ }^{1}$ \\ ${ }^{1}$ Kazan State Power Engineering University, 420066 Kazan, Krasnoselskaya Str. 51, Russia
}

\begin{abstract}
Here, we present the results of numerical studies of biomass gasification using poultry litter, sewage sludge and wood waste (pine shavings) as examples of starting materials. The aim of the study was to find ways to increase the degree of biomass conversion to combustible gaseous products $\left(\mathrm{CO}, \mathrm{H}_{2}, \mathrm{C}_{\mathrm{n}} \mathrm{H}_{\mathrm{m}}\right)$ and to achieve high calorific value of the generated synthesis gas. Modeling biomass gasification was performed for a multicomponent reacting system in a state of thermodynamic and chemical equilibrium. The mathematical model and the calculation program created by the authors were used. The presence of a condensed phase in the form of fine particles of solid carbon and ash in biomass gasification products was taken into account. The optimal levels of gasification temperatures and conditions that help minimizing the concentration of solid carbon particles in gasification products were determined. For optimal biomass gasification, we recommend using the thermal energy obtained from burning part of the generated syngas.
\end{abstract}

\section{Introduction}

Improving the efficiency of thermal utilization of carbon-containing waste (biomass) is a complex scientific and technical problem. The carbon-containing wastes are, e.g., agricultural wastes, wastes from the woodworking industry, poultry litter, and silt sewage sludge. Such wastes can be used as an alternative renewable energy source. The use of carbon-containing wastes to produce heat and electric energy allows reducing the consumption of traditional types of fuel, such as natural gas, oil products, and coal. In addition, improving waste recycling is highly important with regard to the constantly increasing amount of produced wastes that have negative impacts on the environment, e.g., alienating large territories needed for the waste disposal and polluting land and groundwater.

Thermal methods for processing biogenic carboncontaining materials (biomass) include pyrolysis, gasification, and direct combustion. Thermal methods have been developed and applied in many industrialized countries, mostly for the plant biomass utilization [1-3]. Combined options are also considered as promising directions for the development of thermal utilization methods: pyrolysis and subsequent gasification or gasification and subsequent combustion of gas fuels (syngas). The main purpose of gasification processes is the production of a gas fuel (a mixture of $\mathrm{CO}, \mathrm{CO}_{2}, \mathrm{H}_{2}$, $\mathrm{CH}_{4}$, etc.). Gasification can be applied to the carboncontaining wastes as starting materials as well as to the pyrolysis products. The conversion of the starting materials is carried out by applying preheated water vapor, air or oxygen. Air or air enriched with oxygen is supplied in amounts substantially less than stoichiometric, theoretically necessary for the complete combustion. Due to the combustion of part of the biomass, the temperature levels necessary for the implementation of gasification processes are achieved. In most cases, these levels are $800-1000{ }^{\circ} \mathrm{C}$. The energy value of gasification products is due to the concentration of such substances as $\mathrm{CO}, \mathrm{H}_{2}$, and $\mathrm{CH}_{4}$.

With regard to developing new gasifiers, furnace devices, etc., or modernizing existing ones, the major scientific and technical problems are the following: increasing the degree of biomass conversion to combustible gaseous products $\left(\mathrm{CO}, \mathrm{H}_{2}, \mathrm{C}_{\mathrm{n}} \mathrm{H}_{m}\right)$, achieving high completeness of biomass or synthesis gas combustion, and decreasing the concentration of harmful and polluting substances in combustion products. Currently, the solution of such problems is carried out mainly by experimental methods. However, the theoretical analysis of a very complex set of interconnected physicochemical processes is also of decisive importance. Mathematical modeling is an effective approach for solving the mentioned technical problems [4-7]. Mathematical modeling can be used to predict the composition and properties of both gasification products and biomass combustion products. Along with the processes of heat and mass transfer, thermodynamic and chemical processes have to be adequately addressed in the models. The equilibrium [810] and kinetic [11-13] approaches are used in most known models. Many kinetic models are based on the concept of a perfectly stirred reactor, considering detailed mechanisms of chemical reactions. Most commonly, the results of thermo-gravimetric analysis are used to determine the rate constants of biomass gasification reactions. Models using both equilibrium

\footnotetext{
* Corresponding author: alexei demin $@$ mail.ru
} 
and kinetic approaches can be also applied to describe processes in various reaction zones of gasifiers and plants for the synthesis gas or biomass combustion.

Two types of models describing the state of thermodynamic equilibrium can be distinguished. Models of the first type are based on calculating the composition of gasification products using equilibrium constants of biomass gasification reactions (stoichiometric model). In the second type of models, the composition is calculated so that it corresponds to the minimum value of Gibbs free energy (non-stoichiometric model).

The main assumptions accepted in most well-known equilibrium models of biomass gasification are the following [1]:

- all carbon in biomass is converted into gaseous products;

- ash particles and nitrogen are inert and do not participate in gasification reactions;

- the equation of an ideal gas state is applicable to individual gases and the gas mixture as a whole;

- tar formation is considered insignificant;

- pressure is constant and equal to atmospheric;

- there is no temperature gradient inside the reactor;

- as a rule, $\mathrm{CO}, \mathrm{H}_{2}, \mathrm{CO}_{2}, \mathrm{~N}_{2}, \mathrm{H}_{2} \mathrm{O}$ and $\mathrm{CH}_{4}$ are considered as gasification products.

\section{Materials and methods}

A multicomponent reacting system in a state of thermodynamic and chemical equilibrium was considered in the modeling of biomass gasification. At the constant values of pressure and temperature, the equilibrium state corresponds to the minimum value of the isobaric-isothermal potential $G$ (Gibbs energy).The system of equations describing chemical equilibrium for the gas phase consists of nonlinear algebraic equations in a logarithmic form: (i) the law of acting masses (dissociation), (ii) substance conservation equations, and (iii) the equation establishing the equality of partial pressures and the number of moles of substances in the gasification products, as well as the equality of the pressure of the mixture and the total number of moles of substances. The desired parameters are the numbers of moles of substances (molecular and atomic) and the number of moles of fuel. It is accepted that biomass gasification products may contain a condensed phase, for example, in the form of fine particles of solid carbon and ash.

The algorithm based on the representation of the condensed phase as conditional particles with a high number $\left(10^{3}\right.$ or $\left.10^{4}\right)$ of carbon atoms is used to calculate the chemical and phase equilibrium of heterogeneous mixtures [14].

In the presented work, biomass is considered as a mechanical mixture of organic and mineral parts with a certain moisture content.

Biomass moisture depends on storage conditions and can reach high levels, for example, up to $\sim 70$ and $90 \%$ w/w for poultry litter and sewage sludge, respectively.
The organic part of the poultry litter contains mostly carbon and oxygen and to lesser extent hydrogen, nitrogen, and sulfur: $30-45,20-45,3-6,3-6$, and 0.6-0.9 $\% \mathrm{w} / \mathrm{w}$ for $\mathrm{C}, \mathrm{O}, \mathrm{H}, \mathrm{N}$, and $\mathrm{S}$, respectively.

The composition and properties of sewage sludge significantly depend on the type of treated industrial and domestic wastewater. In biological wastewater treatment, silt is present in the sludge in significant quantities.

The organic part of the sewage sludge includes carbon, hydrogen, sulfur, nitrogen and oxygen: $35-88$, 4.5-8.7, $0.2-2.7, \quad 1.8-9.8$, and 7.6-43.2 \% $\quad \mathrm{w} / \mathrm{w}$, respectively.

The chemical compositions of the organic part of the poultry litter and sewage sludge in the dry and ash free basis used for the calculations are shown in Table 1.

Table 1. Chemical compositions of the organic part of poultry litter, and sewage sludge.

\begin{tabular}{|c|c|c|}
\hline $\begin{array}{c}\text { Chemical } \\
\text { elements }\end{array}$ & $\begin{array}{c}\text { Poultry litter, } \\
\text { \% w/w }\end{array}$ & $\begin{array}{c}\text { Sewage sludge, } \\
\text { \% w/w }\end{array}$ \\
\hline $\mathrm{C}$ & 48.03 & 56.53 \\
\hline $\mathrm{H}$ & 6.35 & 7.45 \\
\hline $\mathrm{O}$ & 39.02 & 26.02 \\
\hline $\mathrm{N}$ & 5.90 & 8.50 \\
\hline $\mathrm{S}$ & 0.70 & 1.50 \\
\hline
\end{tabular}

The mineral part of poultry litter and sewage sludge contains compounds of silicon, calcium, aluminum, iron, magnesium, potassium, sodium and others. For example, the mineral part of the silt sewage sludge contains large amounts of $\mathrm{SiO}_{2}, \mathrm{CaO}, \mathrm{Al}_{2} \mathrm{O}_{3}$, and $\mathrm{Fe}_{2} \mathrm{O}_{3}$. These substances were taken into account in the composition of the condensed phase in gasification products.

The chemical compositions of the mineral part of poultry litter and sewage sludge in dry basis used for the calculations are shown in Table 2.

Table 2. Chemical compositions of the mineral part of poultry litter, and sewage sludge.

\begin{tabular}{|c|c|c|}
\hline $\begin{array}{c}\text { Chemical } \\
\text { elements }\end{array}$ & $\begin{array}{c}\text { Poultry litter, } \\
\mathbf{\%} \mathbf{~ w / w}\end{array}$ & $\begin{array}{c}\text { Sewage sludge, } \\
\mathbf{\%} \mathbf{w} / \mathbf{w}\end{array}$ \\
\hline $\mathrm{Si}$ & 31.06 & 20.05 \\
\hline $\mathrm{Ca}$ & 15.62 & 17.45 \\
\hline $\mathrm{Al}$ & 1.45 & 9.42 \\
\hline $\mathrm{Fe}$ & 6.25 & 10.41 \\
\hline $\mathrm{O}$ & 45.62 & 42.67 \\
\hline
\end{tabular}

The calculations were carried out under the condition of external supply of thermal energy necessary to maintain a certain temperature level in the reacting system.

\section{Results and discussion}

The calculations performed for the starting materials in a dry basis showed a high content of condensed carbon $\mathrm{C}^{*}$ in the gasification products. Ash content excluding solid carbon was $15 \% \mathrm{w} / \mathrm{w}$.

For example, at the temperature of $\mathrm{T} \approx 850 \mathrm{~K}, \mathrm{C}^{*} \approx 32$ $\% \mathrm{w} / \mathrm{w}$ in the poultry litter gasification products and $\mathrm{C}^{*} \approx$ $43 \% \mathrm{w} / \mathrm{w}$ in the silt sewage sludge gasification products. 
As the gasification temperature increased to $1273 \mathrm{~K}$, the $\mathrm{C}^{*}$ content decreased to $\mathrm{C}^{*} \approx 18$ and $36 \% \mathrm{w} / \mathrm{w}$ for poultry litter and sewage sludge, respectively.

With increasing moisture content in the starting materials, the calculation results showed a decrease in the content of condensed carbon. For example, at the gasification temperature of $\sim 1273 \mathrm{~K}$, a linear dependence of the $\mathrm{C}^{*}$ content on the moisture content of the starting reagents was revealed. Minimum $\mathrm{C}^{*}$ concentrations were observed at moisture content greater than 25 and $37 \% \mathrm{w} / \mathrm{w}$ for poultry litter and sewage sludge, respectively. Thus, the processes of gasification of the wet biomass are somewhat similar to the processes of steam gasification.

The following results were obtained for the conditions under which the thermal energy necessary for heating and gasification of biomass is obtained from the partial combustion of biomass with air supply. In the starting materials, the content of the mineral part was 15 $\% \mathrm{w} / \mathrm{w}$ and the moisture was $15 \% \mathrm{w} / \mathrm{w}$. Air is supplied in amounts less than stoichiometric ratios for each material.

Table 3 shows the content of combustible gases $\mathrm{H}_{2}$ and $\mathrm{CO}$, nitrogen $\mathrm{N}_{2}$, which is the ballast, the calorific value of wet and dried syngas during gasification of poultry litter for different values of equivalence ratio (ER).

Table 3. Syngas parameters in poultry litter gasification.

\begin{tabular}{|c|c|c|c|c|}
\hline Parameter & \multicolumn{4}{|c|}{ Value } \\
\hline ER & 0.0 & 0.1 & 0.2 & 0.3 \\
\hline $\mathrm{H}_{2}$, vol. \% & 52.50 & 39.38 & 29.36 & 21.94 \\
\hline $\mathrm{CO}$, vol. \% & 43.91 & 37.59 & 29.49 & 23.19 \\
\hline $\mathrm{N}_{2}$, vol. \% & 2.61 & 18.13 & 29.42 & 37.95 \\
\hline $\mathrm{H}_{\mathrm{u}}, \mathrm{kJ} / \mathrm{m}^{3}$ & 11201 & 8990 & 6887 & 5292 \\
\hline $\mathrm{H}_{\mathrm{u}}{ }^{\text {d.b. }}, \mathrm{kJ} / \mathrm{m}^{3}$ & 11233 & 9259 & 7410 & 5882 \\
\hline
\end{tabular}

The same parameters observed for sewage sludge gasification are shown in Table 4.

Table 4. Syngas parameters in sewage sludge gasification.

\begin{tabular}{|c|c|c|c|c|}
\hline Parameter & \multicolumn{4}{|c|}{ Value } \\
\hline ER & 0.0 & 0.1 & 0.2 & 0.3 \\
\hline $\mathrm{H}_{2}$, vol. \% & 60.13 & 42.43 & 32.18 & 23.65 \\
\hline $\mathrm{CO}$, vol. \% & 34.75 & 34.71 & 32.05 & 24.99 \\
\hline $\mathrm{N}_{2}$, vol. \% & 3.83 & 21.92 & 32.49 & 41.34 \\
\hline $\mathrm{H}_{\mathrm{u}}, \mathrm{kJ} / \mathrm{m}^{3}$ & 10864 & 8954 & 7515 & 5704 \\
\hline $\mathrm{H}_{\mathrm{u}}{ }^{\text {d.b. }}, \mathrm{kJ} / \mathrm{m}^{3}$ & 10889 & 8969 & 7647 & 6063 \\
\hline
\end{tabular}

The calculated values of the syngas calorific value obtained from burning part of the biomass were significantly lower than the syngas calorific value obtained with external supply of thermal energy. This is primarily due to the presence of non-combustible substances, mostly $\mathrm{N}_{2}$ and to lesser extent $\mathrm{H}_{2} \mathrm{O}$ and $\mathrm{CO}_{2}$, in the syngas.

Wood biomass (pine shavings) gasification results are presented below.

When performing the calculations, the gasification conditions presented in [15] were simulated.
Initial biomass parameters were the following: 5.6, $0.5,47.68,5.54,37.43,0.05$, and $0.02 \% \mathrm{w} / \mathrm{w}$ for humidity, ash content, $\mathrm{C}, \mathrm{H}, \mathrm{O}, \mathrm{N}$, and $\mathrm{S}$, respectively.

Table 5 shows the temperature of gasification, chemical compositions (vol. \%) of syngas and char residue.

Table 5. Calculated and experimental data.

\begin{tabular}{|c|c|c|c|c|}
\hline Parameter & \multicolumn{5}{|c|}{ Value } \\
\hline $\mathrm{T}, \mathrm{K}$ & 1152 & 1204 & 1277 & $\sim 1273^{*}$ \\
\hline $\mathrm{H}_{2}$ & 45.44 & 47.61 & 49.66 & $50.4^{*}$ \\
\hline $\mathrm{CO}$ & 36.83 & 41.04 & 44.16 & $40.8^{*}$ \\
\hline $\mathrm{CH}_{4}$ & 4.97 & 3.59 & 2.32 & $0.8^{*}$ \\
\hline $\mathrm{CO}_{2}$ & 5.09 & 2.92 & 1.30 & $1.9^{*}$ \\
\hline Char residue, $\mathrm{kg} / \mathrm{kg}$ & 0,22 & 0.20 & 0.18 & $0.21^{*}$ \\
\hline${ }^{*}$ Experimental data [15].
\end{tabular}

The calculated data is in fairly good agreement with the observed experimental data [15].

Kosov et al. [15] propose to use additional steam to increase the energy efficiency of the gasification plant. With a specific water steam consumption of $0.223 \mathrm{~kg} / \mathrm{kg}$, it is expected that char residue will drop to $0.005 \mathrm{~kg} / \mathrm{kg}$. This method was also modeled with the following results. Steam gasification was simulated by increasing the moisture content of the starting material. At the moisture content of 22 and $44 \% \mathrm{w} / \mathrm{w}$, char residue decreased to 0.043 and $0.003 \mathrm{~kg} / \mathrm{kg}$, respectively, supporting the speculation of Kosov et al. [15].

The amount of thermal energy for heating of the reacting system was determined by the formula:

$$
Q=m_{b}\left(h_{g}-h_{b}\right)
$$

where $m_{b}$ - biomass consumption; $h_{g}-$ specific mass enthalpy of gasification products at gasification temperature; $h_{b}$ - specific mass enthalpy of biomass at starting temperature.

Specific mass enthalpy of biomass was determined by the formula:

$$
h_{b}=H_{u}+h_{c p}\left(1+k_{s t}\right)-k_{s t} h_{a i r},
$$

where $H_{u}$ - low calorific value of biomass; $h_{c p}$ - specific mass enthalpy of combustion products at $E R=1.0$ and $T=273 \mathrm{~K} ; k_{s t}-$ mass stoichiometric ratio of air and biomass; $h_{\text {air }}$ - specific mass enthalpy of air.

It was assumed that thermal energy for gasification is obtained by burning a certain amount of generated syngas. This amount is determined by the formula:

$$
m_{s}=Q / H_{u, s}
$$

where $H_{u, s}$ low calorific value of syngas.

For the gasification of poultry litter, sewage sludge and wood waste, the required amount of syngas can reach $\sim 47,52$, and $36 \% \mathrm{w} / \mathrm{w}$ of the total amount of syngas generated, respectively. 


\section{Conclusion}

Gasification of poultry litter and sewage sludge were investigated as a function of chemical characteristic, ash content, moisture, temperature and equivalence ratio.

The temperature levels $(1200-1300 \mathrm{~K})$ optimal for increasing the conversion of biomass to syngas with higher calorific value were determined for the selected conditions.

The initial biomass moisture content values at which the yield of condensed carbon is minimized were revealed.

Obviously, during the gasification with air supply and combustion of part of the biomass, the energy characteristics are significantly lower than during the gasification with external heat supply.

In case of the gasification with air supply, additional thermal energy is required to achieve the optimum temperature level.

In the gasification with an external supply of heat, it is reasonable to obtain this heat by burning part of the generated syngas. The estimated values of the amounts of syngas necessary for this purpose were obtained without considering possible heat losses.

\section{References}

[1] I. Yahyaoui, et al., Advances in renewable energies and power technologies,Biomass, fuel cells, geothermal energies, and smart grids, Elsevier Science, 2 (2018).

[2] P. Basu, Biomass Gasification, Pyrolysis and Torrefaction: Practical Design and Theory, Academic Press (2018).

[3] S. Heidenreich, M. Müller, P.U. Foscolo,Advanced Biomass Gasification: New Concepts for Efficiency Increase and Product Flexibility, Academic Press (2016).

[4] R. Tavares, E. Monteiro, F. Tabet, A. Rouboa, Renewable Energy, 146, 1309-1314 (2020).

[5] S. Yang, H. Wang, Y. Wei, et al., Energy Conversion and Management, 196, 1-17 (2019).

[6] P. Kaushal, R. Tyagi, Renewable Energy, 101, 629-636 (2017).

[7] A. Blanco, F. Chejne, J. of Analytical and Applied Pyrolysis, 118, 105-114 (2016).

[8] A. Gambarotta, M. Morini, A. Zubani, Applied Energy, 227, 119-127 (2018).

[9] A. Mozafari, F.F. Tabrizi, M. Farsi, S.A.H.S. Mousavi, J. of Analytical and Applied Pyrolysis, 126, 415-422 (2017).

[10] J. Han, Y. Liang, J. Hu, et al., Energy Conversion and Management, 153, 641-648 (2017).

[11] J. Yu, J.D. Smith, Chemical Engineering and Processing, 125, 1, 214-226 (2018).

[12] Q. Eri, J. Peng, X. Zhao, Applied Thermal Engineering, 129, 1358-1368 (2018).
[13] H. Goyal, P. Pepiot, Energy Fuels, 31, 11, 1212012132 (2017).

[14] V.I. Naoumov, V.G. Krioukov, A.L. Abdullin, A.V. Demin, Chemical kinetics in combustion and reactive flows: modeling tools and applications, Cambridge University Press (2019).

[15] V.F. Kosov, V.A. Lavrenov, V.M. Zaichenko, J. of Physics: Conf. Ser.,IOP Publishing, 653, 1 (2015). 